\title{
Changing Scenario of Prevalence of Hepatitis B and C Among Blood Donors
}

\section{Syed Riaz Mehdi}

Professor of Hematology and Transfusion Medicine, Division of Hematology, Department of Pathology, Era's Lucknow Medical College, Lucknow, India

*Corresponding author: Syed Riaz Mehdi, Professor of Hematology and Transfusion Medicine, Division of Hematology, Department of Pathology, Era's Lucknow Medical College, Lucknow-226018, India, Tel: 00919506942129; E-mail: riaz_mehdi@hotmail.com

Received date: Dec 15, 2015, Accepted date: Dec 16, 2015, Publication date: Dec 21, 2015

Copyright: (C) 2015 Mehdi SR. This is an open-access article distributed under the terms of the Creative Commons Attribution License, which permits unrestricted use, distribution, and reproduction in any medium, provided the original author and source are credited.

\section{Opinion}

After a gap of almost 15 years when I published my article in the year 2000, entitled "Prevalence of Hepatitis B and C among blood donors" I am trying to review the scenario which has changed during this period. The study was carried out in Saudi Arabia where I had the advantage of studying the prevalence of Hepatitis B and C in different nationalities. There are very few countries where you can get large number of blood donors of different nationalities and ethnicities visiting a single centre. Saudi Arabia is one of those countries because of its dependence on foreign workforce.

Since 2000 when I published this article I have returned back to India. I have gone through the articles published recently on the same subject in India and Saudi Arabia and have noticed a considerable change in the prevalence of Hepatitis $\mathrm{B}$ and $\mathrm{C}$ among blood donors in both these countries. It appears there is a noticeable decline in the prevalence of Hepatitis $B$, while the prevalence of Hepatitis $C$ shows a lowering tend although not as remarkable as of Hepatitis B. The studies carried out and articles published since 2011 onwards from India, including one of our study published in year 2013, [1] and a similar study in the same year from Southern India [2] reports, prevalence of Hepatitis B as $1.9 \%$ and $0.53 \%$ respectively. The much lower prevalence in the Southern states compared to Northern states may be attributed to a successful anti Hepatitis B vaccination and higher literacy rate in the Southern states of India.
Saudi Arabian study published in the same year of 2013 [3] from their Southern province also mentions a remarkable drop in the prevalence of Hepatitis B from 5.6\% in 2004 to 3.8\% in 2011. This may be a result of strict implementation of Saudi's hectic anti Hepatitis B vaccination program.

The prevalence of Hepatitis $C$ has also declined in India, which is reported $0.39 \%$ in the North [4]. In Saudi Arabia the prevalence of anti HCV reported in 2013 is $0.41 \%$ among blood donors which is much lower than $1.0 \%$ reported by me in 2000 . The lower prevalence of Hepatitis $\mathrm{C}$ in these countries in the absence of a vaccine against HCV is only the result of better hygienic conditions and control of transverse and vertical transmission of the disease.

\section{References}

1. Ahmad S, Chaturvedi H, Mehdi SR (2013) Seroprevalence of Hepatitis B virus among blood donors in Shia Muslims in a population of Lucknow. Bang J Med Sci 12: 146-149.

2. Lathamani K, Bhaktha G, Shivananda N, Kotigadde S (2013) Prevalence of HIV, HCV, HBV and Syphilis in Blood donors among the Dakshina Kannada District, India. Int j Curr Microbiol.app Sci 2: 249-252.

3. Abdullah SM (2013) Prevalence of Hepatitis B and C in donated blood from the Jazan region of Saudi Arabia. Malays J Med Sci 20: 41-46.

4. Makroo RN, Walia RS, Chaudhari M, Bhatia A, Hegde V, et al. (2013) Seroprevalence of Anti- HCV antibodies among blood donors of North India. Indian J Med Res 138: 125-128. 